\title{
Elhízással összefüggő csökkent alvásminőség és nem megfelelő alvásidőtartam két erdélyi roma alcsoportban
}

\author{
Szabo Monica Iudita Maria dr. ${ }^{1,2}$ - Máté Beáta dr. ${ }^{2}$ - Frigy Attila dr., 3 \\ ${ }^{1}$ Marosvásárhelyi Orvosi, Gyógyszerészeti, Tudomány- és Technológiai Egyetem, Belgyógyászati Tanszék, \\ Marosvásárhely, Románia \\ ${ }^{2}$ Maros Megyei Sürgősségi Kórház, Belgyógyászati Osztály, Marosvásárhely, Románia \\ ${ }^{3}$ Maros Megyei Klinikai Kórház, Belgyógyászati Osztály, Marosvásárhely, Románia
}

\begin{abstract}
Bevezetés: A rövid alvási idő, illetve a rossz alvásminőség összefüggésben állhat az elhízással, ezen összefüggést azonban még nem tanulmányozták roma populációkban.

Célkitüzés: Alvási szokások tanulmányozása két felnőtt roma alcsoportban (a gazdag gábor és a szegény lovári romáknál), illetve a helyi nem roma lakosságnál, elhízással összefüggésben, tudva, hogy a roma népesség sajátos társadalmi és kulturális jellemzőkkel rendelkezik, gyorsan változó életmóddal.

Módszer: Populációalapú keresztmetszeti felmérést végeztünk Erdélyben, Maros megyében, a Nyárád mentén, ahol nagyobb gábor roma, illetve lovári roma közösség él a magyar populáció mellett. A csoportok nemben és életkorban megfeleltek egymásnak.

Eredmények: Az alvás időtartama 7,18 \pm 1,6 óra volt a gábor romáknál, 7,67 \pm 1,5 óra a lovári romáknál és 7,37 $\pm 1,5$ óra a nem romáknál. Átlagosan a romák 70\%-ánál volt elegendő az alvási idő ( $\geq 7$ óra). A gábor romák 38,6\%-ánál, a lovári romák 27,1\%-ánál és a nem roma lakosság 23,5\%-ánál volt rossz az alvás minősége $(\mathrm{p}=0,05)$. A gábor romáknak szignifikánsan magasabb volt a testtömegindexük $\left(31,1 \pm 4,6\right.$ versus $27,4 \pm 5,2$ és $\left.28,66 \pm 5,7 \mathrm{~kg} / \mathrm{m}^{2}, \mathrm{p}=0,004\right)$, és ez szignifikáns fordított összefüggést mutatott az alvási idővel $(\mathrm{F}=14,85, \mathrm{p}<0,000)$.

Következtetés: A gábor romáknál jóval magasabb arányban fordult elő rossz minőségű alvás. Az alvási időtartam és az alvás minősége összefüggésben volt az elhízással, fơként a roma népesség körében.

Orv Hetil. 2019; 160(32): 1279-1283.
\end{abstract}

Kulcsszavak: elhízás, alvás, roma

Poor sleep quality and inadequate sleep duration related to obesity in two Roma subgroups in Transylvania

Introduction: Short sleep duration and poor sleep quality may be associated with weight gain; this association has not yet been studied in Roma (Gipsy) population.

Aim: Our aim was to study sleep patterns in two adult Roma subgroups (the wealthy Gabor and the poor Lovari Roma), compared to the majority of Hungarian population, in relation to obesity, knowing that Roma population has specific socio-cultural characteristics, with a rapidly changing lifestyle.

Method: A population-based cross-sectional survey was conducted in a rural region in Transylvania, where the above groups are cohabiting. The groups were age- and gender-matched.

Results: Sleep duration was $7.18 \pm 1.6$ hours in the Gabor Roma, $7.67 \pm 1.5$ hours in the Lovari Roma and $7.37 \pm$ 1.5 hours in the non-Roma group. In average, $70 \%$ of them had enough sleep ( $\geq 7$ hours). 38.6\% of Gabor Roma, $27.1 \%$ of Lovari Roma and $23.5 \%$ of non-Roma had poor-quality sleep $(\mathrm{p}=0.05)$. Gabor Roma had significantly higher body mass index $\left(31.1 \pm 4.6\right.$ versus $27.4 \pm 5.2$ and $\left.28.66 \pm 5.7 \mathrm{~kg} / \mathrm{m}^{2}, \mathrm{p}=0.004\right)$, and this correlated inversely with sleep duration $(\mathrm{F}=14.85, \mathrm{p}<0.000)$. 
Conclusion: Gabor Roma had significantly higher percentage of poor-quality sleep. Sleep duration and sleep quality were linked with obesity, mainly in the Roma population.

Keywords: sleep, Roma, obesity

Szabo MIM, Máté B, Frigy A. [Poor sleep quality and inadequate sleep duration related to obesity in two Roma subgroups in Transylvania]. Orv Hetil. 2019; 160(32): 1279-1283.

(Beérkezett: 2019. március 3.; elfogadva: 2019. március 28.)

\section{Rövidítések}

ANOVA $=($ analysis of variance $)$ varianciaanalízis; $\mathrm{BMI}=($ body mass index) testtömegindex; WHR = (waist-hip ratio) derékcsípő hányados

A legújabb népszámlálási adatok alapján Románia lakosságának 3,29\%-a a roma etnikumhoz tartozik. Erdélyben a romák a populáció $4,5 \%$-át teszik ki, de tényleges számuk ennél jóval nagyobbra tehető [1]. A romák sajátos, az északnyugat-indiai populációhoz hasonló genetikai háttérrel rendelkeznek, különleges szociális és kulturális jellemzőkkel bírnak, ugyanakkor az utóbbi évtizedekben jelentősen megváltozott az életmódjuk [2].

Az elmúlt két évtizedben Közép- és Kelet-Európában több, a romák egészségi állapotát felmérő kutatás zajlott [3-6]. Ezek során bizonyítást nyert, hogy az elhízás és a metabolikus szindróma prevalenciája magasabb a roma populációban, és életvitelük egészségtelenebb, bár az adatok néhol ellentmondásosak $[7,8]$.

Véleményünk szerint ezen ellentmondások a roma populáció heterogenitásával magyarázhatók, mivel a különböző csoportok eltérő anyagi háttérrel rendelkeznek, mások a szokásaik, az életvitelük, ezért javasolt az egyes csoportok külön értékelése. Romániában számos roma csoport van, mint például a gábor, a kalderás, a lovári, az oláh, a beás stb. Ezen alcsoportok részben az ősi indiai kasztrendszert tükrözik, de valószínúbb, hogy inkább a különböző földrajzi régiókra jellemző keveredésekből vezethetők le [9], illetve a különböző, jellemző foglalkozásokkal vannak összefüggésben (gyakran a csoportmegnevezés is a hagyományos foglalkozást tükrözi).

Az elégtelen alvási idő szerepe a magasabb cardiovascularis kockázat kialakulásában mára már bizonyított tény [10], ugyanakkor az obesitas és az alvásidő közötti keresztmetszeti kapcsolat felnőttekben bizonyos mértékben ellentmondásos. A felnőtt populáción végzett kutatások eredményei nem olyan egyértelmúek, mint a tizenéveseken végzettek adatai [11].

A szakirodalomból hiányoznak a roma populáción végzett azon epidemiológiai tanulmányok, amelyek az életvitel és az alvási jellemzők összefüggését vizsgálják, illetve amelyek kitérnek a különböző roma csoportok összehasonlítására is. Ebből kiindulva, kutatásunk célja az volt, hogy megvizsgáljuk két roma csoport alvási jel- lemzőit (egy nem roma populációval is összehasonlítva), illetve ezek összefüggését a testtömegindexszel (BMI).

\section{Módszer}

A jelen vizsgálat egy populációalapú keresztmetszeti felmérés része, amelyre Erdélyben, Maros megyében, a Nyárád mentén került sor, ahol nagyobb gábor roma, illetve lovári roma közösség él a magyar ajkú lakosság mellett. A gáborok a romák jellegzetesen Erdélyben élő alcsoportja: aránylag jómódúak, erősen hagyományőrzők, vallásosak, egymás között cigányul beszélnek, habár tanulni a környező többség nyelvén tanulnak (magyarul, románul); zárt közösséget képeznek. A nők négy osztályt végeznek, fiatalon (14-15 évesen) házasodnak, feladatuk a gyermeknevelés, a háztartás. A férfiak általában kereskednek, tavasztól télig külföldön tartózkodnak. A lovári romák (vagy a helyiek megnevezése szerint „házi cigányok") hagyományosan lókereskedéssel foglalkoztak, ma nagyon szegény, alkalmi munkákból tengődő, heterogén, laza struktúrájú, marginalizált roma közösség. A kontrollcsoportba a vizsgálatba bevont falvak nem roma, hasonló korú és nem szerinti eloszlású egyéneit vontuk be; lévén ezek zömében magyar lakosságú falvak, a kontrollcsoport ez esetben magyar populációból állt. A felmérést olyan falvakban végeztük, ahol a roma populáció legalább 100 foós kolóniákban él (Somosd, Karácsonyfalva, Fény, Sárpatak, Nyárádtő). Az egyes csoportokhoz való tartozás saját bevallás alapján történt. A roma közösséget a családorvosokon, illetve roma közösségi vezetőkön keresztül közelítettük meg. A vizsgálatba meghívtunk minden, 18 évnél idősebb roma egyént. A felmérésre helyben, előre meghatározott helyszíneken került sor december és március között, amikor a férfiak is itthon tartózkodnak. A felmérésben részt vevő orvosok és diákok előzetes képzésben vettek részt az adatfelvétel, illetve a vizsgálatok vonatkozásában.

A tanulmányba bekerült mindazon roma személy, aki eljött a vizsgálatra, illetve aláírta a beleegyező nyilatkozatot. Célunk volt a közösség legalább 10\%-ának bevonása: ez csak részben sikerült a roma lakosság egészségügyi rendszerrel szembeni bizalmatlansága miatt, illetve mivel körükben a betegség szégyennek számít, felderítése nemkívánatos. 
Vizsgálatunkba 231 gábor roma, 111 lovári roma és 183 nem roma került be.

A felmérés egy 46 kérdéses, életmód- és szociális viszonyokhoz kötött kérdőív alapján történt, amelyben az alvással kapcsolatos kérdések is szerepeltek. Felmértük az utolsó hónapra vonatkozóan az alvás hosszát, a lefekvés idejét, illetve az alvás minőségét (rossz alvásnak számított, ha az egyén több mint egyszer megébredt, rémálmai voltak, vagy nem tudott elaludni). Elegendőnek tekintettük az alvást, ha az alvásidő legalább napi 7 óra volt [12]. Megmértük a beteg súlyát, magasságát, derék- és csípőkörfogatát. BMI-t és derék-csípő hányadost (WHR) számoltunk. Elhízottnak a minimum $30 \mathrm{~kg} / \mathrm{m}^{2}$-es BMIvel rendelkező egyéneket tekintettük.

A felmérést a Marosvásárhelyi Orvosi, Gyógyszerészeti, Tudomány- és Technológiai Egyetem etikai bizottsága engedélyezte.

Statisztikai analízis: a három etnikai csoport folyamatos változóit ANOVA-teszttel, míg a kategóriás adatokat chi-négyzet-teszttel hasonlítottuk össze. A nemek közötti különbség esetén a folyamatos változókra független t-tesztet alkalmaztunk. A csoporton belüli korrelációt lineáris log-regresszióval vizsgáltuk. Statisztikailag szignifikánsnak a p<0,05 értéket tartottuk. Statisztikai analízisre az SPSS 18-as verzióját (SPSS Inc., Chicago, IL, Amerikai Egyesült Államok) használtuk.

\section{Eredmények}

A felmért populációba 231 gábor roma (átlagéletkor 41,74 $\pm 14,03$ év, 45,8\% férfi), 111 lovári roma (átlagéletkor 40,30 $\pm 14,0$ év, 40,5\% férfi) és 183 magyar lakos (átlagéletkor 44,62 \pm 14,6 év; 41,5\% férfi) került. A fenti csoportok demográfiai és metabolikus paraméterei az 1. táblázatban láthatók.
Tanulmányunkban a gábor romáknak szignifikánsan magasabb volt a BMI-jük, a derék-csípő hányadosuk, és gyakoribb volt az obesitas mind a lovári romákhoz, mind a nem roma populációhoz képest. A csoportok között nem volt különbség az alvás időtartama, a lefekvési idő vonatkozásában. A gábor romáknak a másik két csoporthoz képest szignifikánsan kisebb százalékban volt jó minőségü alvásuk.

Ha a BMI-t és a WHR-t független és az alvásidőtartamot függő változóként kezeltük, szignifikáns fordított összefüggést nyertünk a lineáris regressziós elemzés során $(\mathrm{F}=5,02, \mathrm{p}=0,027$; és $\mathrm{F}=5,98, \mathrm{p}=0,016)$. Ha ezen összefüggést külön vizsgáltuk az egyes csoportokban, szoros összefüggés volt észlelhető a gábor romák esetében $(\mathrm{F}=14,85, \mathrm{p}<0,000)$, kisebb mértékben a lovári romáknál $(\mathrm{F}=3,57, \mathrm{p}<0,05)$, és nem volt összefüggés megfigyelhető a kontrollcsoportban $(\mathrm{F}=0,21, \mathrm{p}=$ $0,64)$.

A jó minőségű alvással rendelkezőknek alacsonyabb volt a BMI-jük $\left(28,4 \pm 5,6\right.$ versus $31,5 \pm 4,7 \mathrm{~kg} / \mathrm{m}^{2}, \mathrm{p}=$ 0,002), ez a különbség azonban csak a gábor roma populációban volt jellemző.

\section{Megbeszélés}

A rövidebb alvási idő, valamint a megromlott alvásminőség jól ismert cardiovascularis kockázati tényezők [13, 14]. A washingtoni székhelyű National Sleep Foundation (Nemzeti Alvás Alapítvány) 2015. évi ajánlása szerint, 18 éves kor felett a legalább 7 óra alvás az egészséges [15].

A roma populáció alvási jellemzőiről mind ez idáig még nem készült tudományos vizsgálat. A szociokulturális különbségek ellenére nem találtunk számottevő különbséget az alvás időtartamát, illetve az ágyban töltött

1. táblázat |A három vizsgált csoport demográfiai és metabolikus jellemzői

\begin{tabular}{|c|c|c|c|c|}
\hline & Gábor roma & Lovári roma & Magyar & $\mathrm{p}$ \\
\hline $\mathrm{N}$ & 231 & 111 & 183 & \\
\hline Életkor (év) & $41,74 \pm 14,0$ & $40,30 \pm 14,0$ & $44,62 \pm 14,6$ & 0,086 \\
\hline $\operatorname{Nem}(\mathrm{n} / \%$ férfi) & $106 / 45,8$ & $45 / 40,5$ & $76 / 41,5$ & 0,451 \\
\hline BMI $\left(\mathrm{kg} / \mathrm{m}^{2}\right)$ & $31,1 \pm 4,6$ & $27,4 \pm 5,2$ & $28,66 \pm 5,7$ & 0,004 * \\
\hline Elhízás $(\mathrm{n} / \%)^{\#}$ & $119 / 51,5$ & $25 / 22,5$ & $47 / 25,6$ & 0,013 * \\
\hline Derékkörfogat (cm) & $102,73 \pm 13,35$ & $89,54 \pm 13,83$ & $98,21 \pm 13,8$ & 0,003 * \\
\hline Derék-csípő hányados & $0,91 \pm 0,1$ & $0,83 \pm 0,0$ & $0,91 \pm 0,0$ & $0,035^{*}$ \\
\hline Az alvás időtartama (órák) & $7,18 \pm 1,6$ & $7,67 \pm 1,5$ & $7,37 \pm 1,5$ & 0,642 \\
\hline A lefekvés ideje (óra) & $22,8 \pm 1,1$ & $22,5 \pm 1,4$ & $22,62 \pm 0,77$ & 0,582 \\
\hline Jó minőségú alvás (n/\%) & $142 / 61,4$ & $81 / 72,9$ & $140 / 76,5$ & $0,05^{*}$ \\
\hline Elegendö alvás (n/\%) & $157 / 67,9$ & $79 / 71,1$ & $127 / 69,3$ & 0,84 \\
\hline
\end{tabular}

Folyamatos változók: átlag \pm SD (standard deviáció)

"Elhízás = BMI $\geq 30 \mathrm{~kg} / \mathrm{m}^{2}$, ahol BMI = testtömegindex 
órák számát tekintve a két roma alcsoport és a nem roma lakosság között. A tanulmányban részt vevő, föként vidéki lakosok átlagos alvási időtartama meghaladta az ajánlott 7 órát, 70\%-ukra volt jellemző az egészséges alvási időtartam. Ez nagyobb százalékos arányt jelent, mint amit Krueger és mtsa egy amerikai felmérésben [16], illetve Balint és mtsai egy 2017-es, Romániában végzett tanulmány során közöltek, ahol Maros megyében a felmért lakosságnak csak az 59,4\%-ánál volt elegendő az alvásidő [17]. Az eredmény egyik lehetséges magyarázata, hogy vidéki környezetben szegényesebb a különböző esti-éjszakai (szabadidős stb.) tevékenységek lehetősége.

Hale és mtsa bebizonyították, hogy az alvási szokásokban etnikai különbségek lehetnek [18]. Tanulmányunkban a gábor roma csoport, mely egy hagyományőrző, szegregáltabb, elhízottabb és gazdagabb roma csoport, rosszabb alvási minőséggel rendelkezett, mint a lovári, illetve a nem roma csoportok $(38,6 \%, 27,1 \%$ és $24,4 \%)$.

A BMI és az alvás időtartama fordított korrelációt mutat [19]. Vizsgálatunkban e korreláció mértéke különbözőnek mutatkozott a különböző csoportokban, magasabb lévén a romáknál. A legnagyobb BMI-vel rendelkező gábor romáknál nagyon erős volt a negatív korreláció a BMI, a haskörfogat és az alvási időtartam között. Ezen túlmenően, a jó alvásminőséggel rendelkező személyek szignifikánsan alacsonyabb BMI-vel rendelkeztek, mint a rossz alvásminőséget mutatók. Ez a megfigyelés igaznak mutatkozott az összes vizsgált csoportban, ugyanakkor a tanulmányban alkalmazott keresztmetszeti vizsgálat nem alkalmas az elhízás és az alvás időtartama közötti ok-okozati összefüggés azonosítására [20].

A vizsgálatba viszonylag kis számú résztvevőt sikerült bevonnunk, aminek egyik oka a roma lakosság gyakran ellenséges magatartása a szűrővizsgálatokkal és az egészségügyi felmérésekkel szemben. Ezeket egyféle közösségellenes agressziónak tekintik; kultúrájukban szégyen a betegség jelenléte, ezért már a betegség diagnosztizálása sem kívánatos számukra. Egy másik lehetséges befolyásoló tényező, hogy a bevallott alvási időtartam nem minden esetben tükrözi a tényleges alvásórák számát [21, $22]$.

\section{Következtetés}

Vizsgálatunk fő erőssége, hogy tudomásunk szerint ez az első olyan tanulmány, mely a roma népesség alvási jellemzőinek vizsgálatával foglalkozott, illetve amely két különböző roma csoportot hasonlított össze.

Kutatásunkban nem találtunk szignifikáns különbséget a gábor roma, a lovári roma és a vidéki magyar populáció alvási paraméterei között, ugyanakkor a gábor roma csoport rosszabb alvásminőséggel rendelkezett. Az elhízás és az alvás időtartama fordítottan korrelált mindkét roma csoportban.
Anyagi támogatás: A tanulmányt a Marosvásárhelyi Orvosi, Gyógyszerészeti, Tudomány- és Technológiai Egyetemen keresztül a SC Cosamext támogatta (Grant nr 13429/2016).

Szerzői munkamegosztás: Sz. M. I., F. A.: A kutatás céljának és módszertanának megtervezése. Sz. M. I., M. B.: Adatgyưjtés, az adatok feldolgozása és kiértékelése. M. B.: A szakirodalom áttekintése. Sz. M. I., F. A., M. B.: A kézirat megszövegezése. Sz. M. I., M. B., F. A.: A kézirat végső változatának áttekintése. A cikk végleges változatát valamennyi szerző elolvasta és jóváhagyta.

Érdekeltségek: A szerzőknek nincsenek érdekeltségeik.

\section{Irodalom}

[1] National Institute of Statistics. Population and Housing Census -2011. [Recensământul populației și a locuințelor 2011.] Available from: http://www.recensamantromania.ro/noutati/volumul-ii-populatia-stabila-rezidenta-structura-etnica-si-confesionala/ [accessed: January 15, 2019]. [Romanian]

[2] Mendizabal I, Lao O, Marigorta U, et al. Reconstructing the population history of European Romani from genome-wide data. Curr Biol. 2012; 22: 2342-2349.

[3] Krajcovicova-Kudlackova M, Blazicek P, Spustova V, et al. Cardiovascular risk factors in young Gypsy population. Bratisl Lek Listy 2004; 105: 256-259.

[4] Weiss E, Japie C, Balahura AM, et al. Cardiovascular risk factors in a Roma sample population from Romania. Rom J Intern Med. 2018; 56: 193-202.

[5] Kósa Zs, Moravcsik-Kornyicki A, Diószegi J, et al. Prevalence of metabolic syndrome among Roma: a comparative health examination survey in Hungary. Eur J Public Health 2015; 25: 299304.

[6] Enache G, Rusu E, Ilinca A, et al. Prevalance of obesity and newly diagnosed diabetes in the Roma population from a county in the south part of Romania (Călărași County) - preliminary results. Rom J Diabetes Nutr Metab Dis. 2016; 23: 27-36.

[7] Vozarova de Courten B, de Courten M, Hanson RL, et al. Higher prevalence of type 2 diabetes, metabolic syndrome and cardiovascular diseases in gypsies than in non-gypsies in Slovakia. Diabetes Res Clin Pract. 2003; 62: 95-103.

[8] Enache G, Rusu E, Ilinca A, et al. Prevalence of overweight and obesity in a Roma population from Southern Romania - Calarasi County. Acta Endocrinol. 2018; 14: 122-130.

[9] Martínez-Cruz B, Mendizabal I, Harmant C, et al. Origins, admixture and founder lineages in European Roma. Eur J Hum Genet. 2016; 24: 937-943.

[10] Hoevenaar-Blom MP, Spijkerman AM, Kromhout D, et al. Sleep duration and sleep quality in relation to 12 -year cardiovascular disease incidence: the MORGEN Study. Sleep 2011; 34: 14871492.

[11] Sólyom R, Lendvai Zs, Pásti K, et al. Sleep duration among school-age children in Hungary and Romania. $[\mathrm{Az}$ alvásidő felmérése Magyarországon és Romániában élő iskoláskorú gyermekek körében.] Orv Hetil. 2013; 154: 1592-1596. [Hungarian]

[12] Hirshkowitz M, Whiton K, Albert SM, et al. National Sleep Foundation's updated sleep duration recommendations: final report. Sleep Health 2015; 1: 233-243.

[13] Hoevenaar-Blom MP, Spijkerman AM, Kromhout D, et al. Sufficient sleep duration contributes to lower cardiovascular disease risk in addition to four traditional lifestyle factors: the MORGEN study. Eur J Prev Cardiol. 2014; 21: 1367-1375. 
[14] Cappuccio FP, Cooper D, D'Elia L. Sleep duration predicts cardiovascular outcomes: a systematic review and meta-analysis of prospective studies. Eur Heart J. 2011; 32: 1484-1492.

[15] National Sleep Foundation. National Sleep Foundation recommends new sleep times. Washington, DC, 2015. Available from: https://sleepfoundation.org/press-release/national-sleepfoundation-recommends-new-sleep-times [accessed: January 15 , 2019].

[16] Krueger PM, Friedman EM. Sleep duration in the United States: a cross-sectional population-based study. Am J Epidemiol. 2009; 169: 1052-1063.

[17] Bálint I, Nemes Nagy E, Csibi M, et al. The role of diet and lifestyle habits in prevention of cardiovascular diseases in Moldavian and Transylvanian population. Rev Chim. 2017; 68: 14601465.

[18] Hale L, Do DP. Racial differences in self-reports of sleep duration in a population-based study. Sleep 2007; 30: 1096-1103.
[19] Kim HJ. Sleep duration and obesity. J Obes Metab Syndr. 2017; 26: 1-2.

[20] Knutson KL, Van Cauter E. Associations between sleep loss and increased risk of obesity and diabetes. Ann N Y Acad Sci. 2008; 1129: 287-304.

[21] Lauderdale DS, Knutson KL, Yan LL. Self-reported and measured sleep duration: how similar are they? Epidemiology 2008; 19: 838-845.

[22] Van den Berg JF, Van Rooij FJ, Vos H, et al. Disagreement between subjective and actigraphic measures of sleep duration in a population-based study of elderly persons. J Sleep Res. 2008; 17: 295-302.

(Szabo Monica Iudita Maria dr., Gheorghe Marinescu u. 38., 540139 Marosvásárbely, Románia e-mails: szabo.monika@umftgm.ro, sztamo@gmail.com)

\section{"Non qui parum habet, sed qui plus cupit, pauper est." (Seneca) (Nem az a szegény, akinek kevés van, hanem aki többre vágyik.)}

